\title{
Is the inclusion of first-year assessment in the calculation of GPA deleterious to students from a Widening Participation Background?
}

\author{
Alicja Konstantinidis-Pereira and Ian Scott* \\ Oxford Brookes University, Oxford, United Kingdom
}

i.scott@brookes.ac.uk Tel: 01865485357

Oxford Brookes University, Faculty of Health and Life Sciences, Headington Campus, Oxford, OX3 0BP

Dr Ian Scott is Associate Dean - Student Experience in the Faculty of Health and Life Sciences at Oxford Brookes University.

akonstantinidis@brookes.ac.uk Tel: 01865484939

Oxford Brookes University, Strategic and Business Planning Office, Headington Campus, Oxford, OX3 0BP

Alicja Konstantinidis-Pereira is Strategic Planning Manager at Oxford Brookes University.

* author for correspondence 


\title{
Is the inclusion of first-year assessment in the calculation of GPA deleterious to students from a Widening Participation Background?
}

\author{
The use of Grade Point Average (GPA) as a means to summarise learning is a novel \\ practice in the UK. The aim of this study was to determine if the inclusion of \\ assessment results from student's first year of study in the calculation of GPA is \\ deleterious to students from a widening participation background (WPB). Assessment \\ marks of full time undergraduate students were investigated using statistical modelling. \\ The inclusion of the assessment outcomes from the first year of studies in the \\ calculation of GPA was significantly beneficial to BAME and Mature students on their \\ overall GPA and not disadvantageous to any group of WPB students. Our analysis \\ highlighted how the traditional UK degree classification system, as used by Oxford \\ Brookes University tends to magnify the presentation of the difference in learning \\ achieved by different groups of students when compared to that shown by the GPA or \\ raw marks.
}

Keywords: Grade point average, GPA, Widening Participation, Black and Minority Ethnicity

\section{Introduction}

Grade point average, often known by its acronym GPA is a commonly used method to summarise students' academic achievement over a period of time. The period of time is normally the duration of an academic award, although GPA can also be used to summate achievement at the end of common academic study periods such as semesters or terms. As its name implies GPA is a calculation based upon the average of the grades achieved across the modules/courses taken. Whilst the use of GPAs is relatively common across HEI institutes where English is the medium of education, it is little used within the UK which has hitherto used a categorical scale, normally with 6 points (First, Upper Second, Lower Second, Third, Pass, and Fail) to provide a summary of its students' academic achievements at the end of their degree. This categorical system contrasts sharply with the continuous scale of the GPA. 
Within the context of how achievement in higher education is recorded for UK undergraduates there has been a level of discord with the traditional degree classification system. Concerns focus on three areas, lack of transparency in relation to how differing institutions calculate their classifications, poor international portability and the limited granularity of the degree classification meaning that differentiating between graduates is difficult. GPA is supported as an alternative by some as an antidote to these concerns, furthermore it has postulated that; as GPA can be calculated continuously across the undergraduate 'lifespan' that it will enhance engagement and that it could act as a break on what is perceived as unwarranted inflation in the category of degree classifications awarded.

This discord led to the Measuring and Recording Student Achievement Scoping Group declaring the UK honours degree classification system as 'not fit for purpose' (UUK 2007). The Burgess Group itself went on to recommend an exploration of GPA as potentially part of system for measuring and recording achievement of UK undergraduates (UUK 2007). GPA was further discussed in relation to the Higher Education Achievement Record (HEAR) largely in the context of bringing consistency to the ways in which degree classifications are generated at differing institutions across the UK. Following the publication of the UUK (2012) final report a number of Universities in the UK started work on implementing a GPA system (see HEA 2015).

The introduction of GPA at Oxford Brookes provides an excellent opportunity to examine the impact of a different classification system (at least in the UK) on students' study performance and outcomes. Whilst recognising that the use of GPA is an established practice in many parts of the world, the GPA system in itself is not without contest, particularly in relation to grade inflation.

At Oxford Brookes University GPA was introduced in 2013, the implementation and initial impact of this introduction have been described elsewhere (Andrews 2016). One of the 
considerations when devising a GPA system is the methodology through which the GPA will be calculated. By methodology we mean how grade points are translated into an average (Andrews 2016), this would include for example, whether or not there is any weighting and which if any modules/courses are excluded. A common debate is whether or not to include modules/courses that are undertaken in the first level of degree study (HEA 2015) now referred to as level 4 (QAA 2014). Some consider that including students' performance from the first level of study could disadvantage: those students that come from backgrounds where prior exposure to the nature of higher education and its ways of working are less likely to be known and, those that are returning to study. Collectively these students are often known as students from widening participation (WP) backgrounds. At Oxford Brookes it was decided that our GPA methodology would:

- be based on the arithmetic mean of the summative module grade weighted by module credit value (converted into a point score);

- include all module grades;

- include the first level (level 4).

Given that in this methodology, student performance from the outset of their studies would be included in the GPA there was a concern that widening participation students may be disadvantaged. In this paper we examine the hypothesis that the GPA of WP students will be lower than that of non-WP students. We examine this hypothesis by analysing the difference between academic performance of WP and non-WP students pre and post implementation of GPA. We use the performance of students in a particular year as measured by the modules summative assessment mark expressed as a percentage.

The analysis we have undertaken focuses on two elements. The first one examines the impact of the GPA introduction on module results - whether we can see any 
change/improvement in exam results following the GPA introduction. The second theme of the research analyses the influence of including Stage 1 assessment results and whether any adverse effects may be specific to a particular group of students (especially those from underrepresented WP backgrounds). The research explores not only whether their assessment results are lower but specifically if there is bigger difference between their Stage 2 and Stage 1 average module mark as then they would be particularly disadvantaged by including Stage 1 modules in their GPA calculations. At Oxford Brookes Stage 1 equates to level 4 of the Framework for Higher Education Qualifications (QAA 2014) used in the UK, whilst stage 2 levels 5 and 6 of the framework.

In order to answer both research questions the analysis looks at the possible relationship between student and course characteristics and student assessment performance calculated as the average of their percentage module results. The averages were based on all assessment results (including failed assessments). We excluded results that would not be considered by the University for inclusion in the GPA, for example where an assessment grade had been discounted through mitigating circumstances.

\section{Method}

In our analysis the attainment, we included two cohorts of students - 2013/14 cohort start year (the year of the GPA introduction at Oxford Brookes University) and 2012/13 cohort start year. In order to have as comparable results as possible and compatible with the WP definitions, the data were limited to Oxford Brookes study location (excluding courses taught at our partner colleges), UK-domiciled, UG First Degree students, on modular degree, fulltime (both in terms of entry and leaving study mode), Oxford Brookes study location, stage 1 and semester 1 entrants who completed their course successfully. The dataset consists of 3,523 students (subject weighted) from both cohorts. 
In order to answer the two research questions regarding the impact of the GPA introduction on module results (1) and the effect of including Stage 1 assessment results on underrepresented groups of students from WP backgrounds (2), a series of linear regression modelling was conducted in SPSS. The dependent variables were: Average mark (all modules), Stage 1 average mark, Stage 2 average mark and Difference between Stage 2 and Stage 1 average mark. Multivariate models checked if there is a relationship between student assessment performance and their characteristics: gender (male vs female), ethnicity (both binary Black, Asian and Minority Ethnic (BAME) vs White; and detailed: Asian, Black and Other vs White), entry age (Mature (without honours degree) vs Young), disability, low participation area (POLAR 1 and 2 quintiles). Initially socio-economics group (lower vs higher) and parental education (non-HE vs HE) were also considered but initial statistical tests (ANOVA) showed no differences in average mark and in other dependent variables. In assessing the impact of one characteristic, it is often necessary to perceive students in a multidimensional way as it is possible that influence of one characteristic moderates the influence of the other. Two main controlling factors for regression models were average entry tariff and subject of study (18 standard broad subject areas (JACS 3.0 see HESA 2018) were used by grouping three pairs of smaller subjects: Physical and mathematical sciences, Engineering and technology as well as European and non-European languages; students in the analysed dataset were in 16 subject areas). These linear regression models have in the majority of cases a very low coefficient of determination $\left(\mathrm{R}^{2}\right)$ but they do not aspire to build a fully explanatory picture and modelling of exam results. The aim was to confirm the impact of GPA and differences in performance by certain student WP characteristics. 


\section{Results}

\section{Average module mark distribution}

Figure 1 summarises the differences between the distribution of three types of module mark averages (all modules - solid line; Stage 1 - dashed line and Stage 2 - dotted line). Stage 2 modules average is more concentrated around a 60-65 mark interval, whereas the Stage 1 average is more evenly distributed and has more of the values in the lowest but also in the three highest intervals.

[Figure 1 near here]

Figure 2 shows the distribution of the differences between Stage 2 and Stage 1 average module mark with both positive (Stage 2 module mark higher than Stage 1 module mark average) and negative differences (Stage 1 module mark higher than Stage 2 module mark average). There were more positive differences ( $65 \%$ vs $35 \%$ of all observed differences). It is also important to note that around one quarter of differences (26\%) were within \pm 2 percentage points, a half (51\%) within \pm 4 points and $82 \%$ within \pm 8 points.

[Figure 2 near here]

Table 1 summarises the differences in average module mark by analysed characteristics.

[Table 1 near here]

\section{Impact of the GPA introduction}

The first research question considered the possible positive impact of the GPA Introduction on average module mark. Our hypothesis was that including Stage 1 modules in the summative GPA results could encourage better performance in those early exams. As a result it would therefore also increase the overall average module mark across all years of study. 
The second hypothesis was that the GPA introduction might potentially also have a positive impact on Stage 2 results. Even though these exams are included in the traditional degree classification, the impact of the GPA and continuous monitoring of student performance could also influence better results at later stages of the degree.

Tables 2-4 summarise the results of regression modelling of average module mark (Overall, Stage 1 and Stage 2 separately) for the two analysed cohorts (pre- and post-GPA introduction) to assess if we can see any positive impact of GPA on student performance. The models control for subject, entry tariff and three student characteristics with a statistically significant influence on module results: gender, ethnicity and entry age. The modelling confirms a statistically significant influence of the GPA introduction on Stage 1 average module mark (increasing it by over 1 point -1.06 ); the impact on all modules average mark is smaller (increasing it by circa 0.5 point on average -0.47 ). Regarding the second hypothesis, there is however no statistically significant influence on Stage 2 results.

Traditionally student performance at the second stage of their degree expressed as the average module mark has been higher (vide figure 1 in the previous section) with the majority of the differences between Stage 2 and Stage 1 results being positive (in favour of Stage 2 results - vide Figure 2 in the previous section). Considering the positive impact of the GPA introduction on Stage 1 results and no confirmed impact on Stage 2 results, the third hypothesis in this section would be to assess if there is any statistically significant influence of GPA introduction on the difference between Stage 2 and Stage 1 performance. The modelling of this new variable can be found in table 5 in the next section of this paper. Indeed controlling for subject of study (as well as ethnicity and entry age), the GPA introduction seems to have an impact on the difference between Stage 2 and Stage 1 results (vide table 5 in the next section), closing the gap between the two average marks. 
Through the increase in the Stage 1 average module mark, the positive impact of the GPA introduction not only means better results in the early stages of a degree but also a more even performance across student lifecycle at the university.

[Table 2 near here]

[Table 3 near here]

[Table 4 near here]

\section{Differences in average mark by WP characteristics}

After evaluating the impact of the GPA introduction on module results, the second main research theme considers the differences in performance of WP students in general and at different stages of their degree with the particular focus of the initial stages of their degree (omitted in the traditional degree classification and included in the new GPA calculation). Initially we analysed overall differences in average module marks taking these characteristics into account. The regression modelling (vide the regression models in tables 2-4 in the previous section) allowed us to quantify the differences at the most granular level of average module mark. Controlling for entry tariff and subject of study, the main statistically significant general differences in average module marks (all modules, Stage 1 and Stage 2 separately) by student characteristics can be summarised as follows:

- Male students had on average 0.60 point lower assessment results than female students (for all three analysed average module marks).

- There were also statistically significant differences in the performance of Black, Asian and Minority Ethnic students. On the most general aggregated level, our regression modelling showed that BAME students have on average overall module marks lower by 1.90 point than their White peers. Interestingly, the difference is 
smaller for Stage 1 results (1.27 points) and higher for Stage 2 results (2.26 points). When analysing ethnic minority groups in details, all three BAME groups have lower module results than their White peers. The differences are the most substantial for Black students - their results are on average lower by 2.61 points in comparison with White students (1.45 for Stage 1 and the difference increases to 3.23 for Stage 2). Asian students' results are lower on average by circa 1.53 points (1.32 for Stage 1 and 1.67 for Stage 2). Students from Other ethnic minority groups have module marks lower by 1.79 points on average (1.16 points for Stage 1 and 2.16 points for Stage 2 ).

- Mature students (without honours degree), on the other hand in general achieve better results than their peers (2.20 points higher average module marks - the difference is bigger for Stage 1: 3.17 points and lower for Stage 2: 1.85 points).

There were no statistically significant differences in module marks by disability and by POLAR. Interestingly the latter showed some significant differences in the initial tests (including just this one variable). The multivariate model however did not confirm them. Low participation area is strongly related to two other WP characteristics - ethnicity (a higher proportion of students from ethnic minority backgrounds) and entry age (a significantly higher percentage of mature students with no prior honours degree).

\section{Differential performance of WP students and GPA}

As described in the previous section, the regression modelling confirmed statistically significant differences in Overall, Stage 1 and Stage 2 average module mark by gender, ethnicity and entry age. The final research question in our analysis of the GPA introduction and its impact on WP students focuses on the modelling of the difference between Stage 2 and Stage 1 performance whether it is higher for WP students. If this difference was 
relatively bigger for these WP groups than their non-WP peers, these students would be disadvantaged by including these early results in their overall GPA.

The initial modelling of Stage 1 and Stage 2 results separately (described above) could be seen as not supporting this hypothesis, as it showed the smaller negative differences at Stage 1 than at Stage 2 for BAME students vs White; and the bigger positive differences for Mature students (vs Young) at Stage 1 than at Stage 2.

In order to assess this observation further a separate regression model was built where the dependent variable was a difference between Stage 2 and Stage 1 average module mark. Three models were built (one for each cohort and one for both cohorts which also confirmed the impact of GPA introduction on the difference between Stage 2 and Stage 1 results). The models summarised in tables $5,5 \mathrm{a}$ and $5 \mathrm{~b}$ look at two analysed cohorts together as well as the pre-GPA and post-GPA introduction cohort separately. While these models assess the impact of ethnicity in four ethnic groups, the models with the binary ethnicity variable (BAME vs White) were also built.

In general controlling for subject of study (average entry tariff does not have any significant influence on the difference between Stage 2 and Stage 1 performance); there are statistically significant differences for two WP characteristics - ethnicity and entry age. For these WP students the difference between Stage 2 and Stage 1 results is relatively smaller than for their non-WP peers:

- Controlling for subject of study, entry age (Mature students without a prior honours degree) has a statistically significant influence on the difference between Stage 2 and Stage 1 module results (decreasing it by over 1 point -1.25 vide table 5 ). As summarised in the previous section of this paper, controlling for other factors, mature students do on average better than younger students in their assessments - the 
difference in module marks is particularly highe for Stage 1 modules (vide tables 3 and 4 in the previous section).

- Controlling for subject of study, ethnicity (BAME) has a statistically significant influence on the difference between Stage 2 and Stage 1 module results (decreasing it by circa 1 point -0.95 vide table 5 ). The difference is particularly substantial for Black students in comparison with their White peers. As described in the previous section, statistically controlling for other factors (entry tariff and subject of study in particular) students from ethnic minority groups have a lower overall as well as Stage 1 and Stage 2 module average mark than other students (vide tables 3 and 4). However, the difference between BAME and White students is much smaller for Stage 1 results (lower by circa 1.26 point) than Stage 2 results (lower by 2.10 points).

Therefore in general students from WP backgrounds are not disadvantaged by including Stage 1 results in their module mark average.

[Table 5 near here]

[Table 5a near here]

[Table $5 \mathrm{~b}$ near here]

\section{Differential performance of WP students - GPA and degree classification}

The regression models summarised in the previous sections of this paper show statistically significant differences in performance of students by WP characteristics. The average module mark used in these models summarises the results in the most detailed way. It is important to see how these module mark differences are translated to the differential outcomes in the GPA and degree classification. We analysed the difference in GPA (linear regression modelling with similar assumptions to average module mark models, controlling for subject of study and 
entry tariff) and in the probability of obtaining a first or upper second class degrees out of all honours degrees (first, upper second, lower second and third class) as well as a first class degrees only (both using binary logistic regression modelling controlling for subject of study and entry tariff). The summary can be seen in table 6 .

[Table 6 near here]

Controlling for subject of study and entry tariff, both the GPA and the degree classification modelling separately showed some significant differences by ethnicity. BAME students GPA is just 0.18 points lower than their White peers. The differences for black students are slightly greater $(0.24)$. The differences in degree classification however are much more substantial - controlling for subject and entry tariff BAME students are 54\% less likely to obtain a first or upper second class degree than White students (again the differences are the highest for Black students $-64 \%$ less likely).

The differences in attainment by entry age are more complex. In the one dimensional perspective, there appear to be no differences in both average module mark and GPA between mature and young students. However there are substantial differences by subject of study and entry tariff between these two groups. Using the multidimensional analysis controlling for subject and entry tariff, mature students in general have a higher average module mark than young students (by 2.2 module mark points); their GPA is also higher by 0.18 grade points. When their good completion (defined as a percentage of a first or upper second class degrees) is analysed, it appears that the attainment of mature students is lower ( $73.3 \%$ of mature students obtained a 1 st or 2.1 vs $82.5 \%$ of their younger peers). However when this attainment gap is analysed controlling for subject of study and entry tariff, these differences are not statistically significant. In fact there are statistically significant differences (controlling for subject and tariff) when the focus is only on the first class degree, mature 
students without a degree are 2.6 times more likely to obtain a first class degree than their young peers.

\section{Discussion}

Our analysis demonstrates that for the cohorts analysed the inclusion of the assessment outcomes from the first year of studies in the calculation of GPA was not disadvantageous to students from a widening participation background. For two groups of widening participation students, BAME and Mature students the inclusion of first year assessment outcomes has a significant beneficial influence on their overall GPA. This result is contrary to our initial expectations, where we hypothesised that owing to the supposed longer time needed by WP students to learn the norms of higher education at the institute they are attending (Reay, Crozier and Clayton 2007) that they would take longer to meet their learning potential. It is however the case that most of the literature on students from widening participation backgrounds' success and adaption to university focusses on retention and the greater propensity of these students to drop-out early.

It is important to note that our analysis suggests that most WP groups perform less well than in Stage 1 (first year) than their non-WP counterparts, and that it is the difference in learning trajectories of these groups of students that means not including Stage 1 assessment result would lead to disadvantaging some of these groups. These results do not suggest that WP students are slower to adapt to University than non-WP students. It may be that for many WP students full adaption never occurs (Reay Crozier and Clayton, 2010; Reay et al. 2001). To an extent our results concords with earlier work by Pokorny and Pokorny (2005), which indicated that rather than measures of prior attainment or background the best predictor of academic success in the first year of study was amount of effort (as measured by time) applied to the assessment task. 
Our results with respect to the absolute academic performance of WP students are consistent with those reported elsewhere (see for example Hoare and Johnston 2011 and Mountford-Zimdars et al. 2017) with students, classified as WP fairing less well at a statistically significant level. The difference being most pronounced for BAME students particularly when compared to students classified as white. Surprisingly however, the actual difference in terms of the average module mark is relatively small. Between BAME and White students this difference is only 2.36 module mark points, yet for this cohort of students the difference in terms of degree classification was much more substantial. Controlling for subject and entry tariff, BAME students are 54\% less likely to obtain a first or upper second class degree (the percentages completing with a 1 st or 2.1 are $69.4 \%$ for BAME and $83.7 \%$ for White). In terms of GPA, the difference in GPA calculated from mean module grade for each stage would be just 0.18 grade controlling for entry tariff and subject of study (the actual overall GPA $=3.0$ for White and 2.78 for BAME students). Thus with respect to how Oxford Brookes University calculates its GPA and Degree Classifications, the GPA system appears to magnify the performance difference at modular level to a far lesser extent and suggests that it is more reflective of actual performance at the module level.

In terms of assessing the performance of mature students without honours degree the GPA system appears to bring an important additional perspective. Unlike the traditional degree classification which would highlight lower attainment (or no difference in attainment controlling for other factors), the GPA by directly translating the detailed module results brings the message of higher average performance vs their younger peers. Even within the degree classification scale the attainment by entry age has its own complexities - mature students have a higher proportion of degrees at both ends of the spectrum. A higher percentage of them vs their younger peers graduate with the lower second and third class but at the same time relatively substantially more graduate with a first class degree. When the 
results are analysed controlling for subject of study and entry tariff, only the latter (the better attainment and the likelihood of achieving a first class degree) is statistically significant. The GPA system again appears to be much closer to the modular level performance and as such it adds an important element to the performance measurement of mature students.

This study is limited by having data from just one University, which restricts the extent to which the findings are applicable to other universities that may have different systems of assessment, degree classification and cultural practices. With respect to GPA, the extent to which data is available across institutions is limited by the low level of adoption thus far of the GPA system. Nevertheless this study provides significant pointers for institutions considering the implementation of GPA, and we can confirm that at Oxford Brookes, using first year results in the calculation of GPA is not deleterious. We also find that contrary to the commonly held view, our WP students do not have a lower learning trajectory (as determined by formal assessment) than non-WP students.

Serendipitously this study found that at Oxford Brookes, there is a large difference between the performance of BAME students as expressed by the traditional degree classification and that seen at module level. This finding suggest that the large difference in degree classification between BAME and non-BAME students may be largely generated by factors within the system that the University uses to produce degree classifications rather than significant difference in academic performance. Were this finding to be common across HEIs it would have significance for the debate on the differential performance of BAME and nonBAME students which is significant within the sector in the UK. 
No potential conflict of interest was reported by the authors.

References

Andrews, M. 2016 The why, what and impact of GPA at Oxford Brookes University, Perspectives, Policy and Practice in Higher Education, 20(4) pp121-128.

HEA 2015. Grade Point Average: Report of the GPA pilot project 2013-14. York, Higher Education Academy.

HESA 2018. JACS 3.0: Principal subject codes. [ONLINE] Available at: https://www.hesa.ac.uk/support/documentation/jacs/jacs3-principal. [Accessed 27 April 2018].

Hoare, A. and Johnston, R. 2010 Widening participation through admissions policy - a British case study of school and university performance. Studies in Higher education 36,1 pp $21-41$

Mountford-Zimdars, A, Sanders, J, Moore, J, Sabri, D, Jones, S, \& Higham, L 2017, 'What Can Universities Do to Support All Their Students to Progress Successfully throughout Their Time at University?', Perspectives: Policy And Practice In Higher Education, 21, 2-3, pp. 101-110.

Pokorny, M. and Pokorny, H. (2005) Widening participation in higher education: student quantitative skills and independent learning as impediments to progression. Journal of Mathematical Education in Science and Technology, 36 (5). pp. 445-467.

QAA (2014) UK Quality Code for HE Part A: Setting and Maintaining Academic Standards:

The Framework for Higher Education Qualifications of UK Degree Awarding Bodies, Gloucestershire, QAA

Raey, D. Crozier, G. and Clayton, J. 2010. 'Fitting in or standing out ' Working class students in UK Higher Education. British Educational Research Journal 361 107-124.

Reay, D., Davies, J., David, M., \& Ball, S. 2001. Choices of Degree or Degrees of Choice? Class, 'Race' and the Higher Education Choice Process. Sociology, 35(4), 855-874.

UUK 2007. Beyond the honours degree classification, The Burgess Group final report.

London, Universities UK

UUK 2012. Bringing it altogether: Introducing the HEAR. London, Universities UK. 
Figure 1. All modules, Stage 1 and Stage 2 modules average mark distribution (2012/13 and 2013/14 cohort start year)

[provided separately]

Figure 2. Difference between Stage 2 and Stage 1 average module mark distribution (2012/13 and 2013/14 cohort start year)

[provided separately]

Table 1. Student characteristics and average module marks

\begin{tabular}{|c|c|c|c|c|c|c|c|}
\hline & Variable & $\begin{array}{c}\% \\
\text { student } \\
\text { s }\end{array}$ & $\begin{array}{c}\text { Avera } \\
\text { ge } \\
\text { modu } \\
\text { le } \\
\text { mark }\end{array}$ & $\begin{array}{c}\text { Stage } \\
1 \\
\text { avera } \\
\text { ge } \\
\text { modu } \\
\text { le } \\
\text { mark }\end{array}$ & $\begin{array}{c}\text { Stage } \\
2 \\
\text { avera } \\
\text { ge } \\
\text { modu } \\
\text { le } \\
\text { mark }\end{array}$ & $\begin{array}{c}\text { Statistical } \\
\text { significan } \\
\text { ce - initial } \\
\text { testing } \\
\text { ANOVA }\end{array}$ & $\begin{array}{l}\text { Statistical } \\
\text { significan } \\
\text { ce - } \\
\text { multivari } \\
\text { ate } \\
\text { regression }\end{array}$ \\
\hline \multirow{3}{*}{ Gender } & Female & $59.44 \%$ & 61.99 & 60.66 & 62.72 & \multirow{3}{*}{$\begin{array}{l}\text { Yes for all } \\
\text { three } \\
\text { averages* }\end{array}$} & \multirow{3}{*}{$\begin{array}{l}\text { Yes for all } \\
\text { three } \\
\text { averages* }\end{array}$} \\
\hline & Male & $40.56 \%$ & 61.34 & 60.07 & 62.09 & & \\
\hline & Total known & \multicolumn{4}{|c|}{ Known for all } & & \\
\hline \multirow{6}{*}{ Ethnicity } & BAME: & $14.59 \%$ & 59.71 & 58.92 & 60.21 & \multirow{6}{*}{$\begin{array}{c}\text { Yes for all } \\
\text { three } \\
\text { averages* } \\
* *\end{array}$} & \multirow{6}{*}{$\begin{array}{c}\text { Yes for all } \\
\text { three } \\
\text { averages } * \\
* *\end{array}$} \\
\hline & - Asian & $3.87 \%$ & 60.10 & 58.93 & 60.84 & & \\
\hline & - Black & $3.76 \%$ & 58.69 & 58.37 & 58.92 & & \\
\hline & - Other & $6.97 \%$ & 60.04 & 59.22 & 60.55 & & \\
\hline & White & $85.41 \%$ & 62.07 & 60.68 & 62.85 & & \\
\hline & Total known & \multicolumn{4}{|c|}{ Known for $99 \%$} & & \\
\hline \multirow{3}{*}{$\begin{array}{l}\text { Entry } \\
\text { age }\end{array}$} & $\begin{array}{l}\text { Mature (without honours } \\
\text { degree) }\end{array}$ & $9.99 \%$ & 61.82 & 61.64 & 62.06 & \multirow{3}{*}{$\begin{array}{c}\text { Only } \\
\text { Stage } 1 \\
\text { average** }\end{array}$} & \multirow{3}{*}{$\begin{array}{c}\text { Yes for all } \\
\text { three } \\
\text { averages* } \\
* *\end{array}$} \\
\hline & Young & $90.01 \%$ & 61.71 & 60.29 & 62.50 & & \\
\hline & Total known & \multicolumn{4}{|c|}{ Known for all } & & \\
\hline \multirow{3}{*}{$\begin{array}{c}\text { Disabilit } \\
\mathrm{y}\end{array}$} & Disabled & $17.88 \%$ & 61.50 & 60.05 & 62.31 & \multirow{3}{*}{ No } & \multirow{3}{*}{ No } \\
\hline & No disability & $82.12 \%$ & 61.77 & 60.50 & 62.49 & & \\
\hline & Total known & \multicolumn{4}{|c|}{ Known for all } & & \\
\hline \multirow{3}{*}{$\begin{array}{l}\text { Low } \\
\text { participat } \\
\text { ion area }\end{array}$} & POLAR Q1 \& Q2 & $17.04 \%$ & 61.52 & 60.69 & 62.03 & \multirow{3}{*}{$\begin{array}{c}\text { Only } \\
\text { Stage } 2 \\
\text { average* }\end{array}$} & \multirow{3}{*}{ No } \\
\hline & POLAR Q3-5 & $82.96 \%$ & 61.80 & 60.40 & 62.58 & & \\
\hline & Total known & \multicolumn{4}{|c|}{ Known for $99.4 \%$} & & \\
\hline
\end{tabular}




\begin{tabular}{|c|c|c|c|c|c|c|c|}
\hline \multirow{3}{*}{$\begin{array}{l}\text { GPA } \\
\text { Introduct } \\
\quad \text { ion }\end{array}$} & Yes $(2013 / 14)$ & $44.45 \%$ & 61.61 & 60.09 & 62.49 & \multirow{3}{*}{$\begin{array}{c}\text { Only } \\
\text { Stage } 1 \\
\text { average* }\end{array}$} & \multirow{3}{*}{$\begin{array}{l}\text { Yes for } \\
\text { All } \\
\text { modules } \\
\text { and for } \\
\text { Stage } 1\end{array}$} \\
\hline & No $(2012 / 13)$ & $55.55 \%$ & 61.81 & 60.69 & 62.44 & & \\
\hline & Total known & \multicolumn{4}{|c|}{ Known for all } & & \\
\hline \multirow{16}{*}{ Subject } & Subjects allied to medicine & $12.66 \%$ & 62.84 & 62.34 & 63.12 & \multirow{16}{*}{$\begin{array}{l}\text { Yes for all } \\
\text { three } \\
\text { averages* } \\
* *\end{array}$} & \multirow{15}{*}{$\begin{array}{l}\text { Yes for all } \\
\text { three } \\
\text { averages* } \\
* *\end{array}$} \\
\hline & Biological sciences & $12.63 \%$ & 61.98 & 61.29 & 62.40 & & \\
\hline & $\begin{array}{l}\text { Physical and mathematical } \\
\text { sciences }\end{array}$ & $1.47 \%$ & 62.19 & 64.57 & 61.03 & & \\
\hline & $\begin{array}{l}\text { Engineering and } \\
\text { technologies }\end{array}$ & $2.90 \%$ & 64.34 & 64.47 & 64.35 & & \\
\hline & Computer science & $1.50 \%$ & 66.05 & 66.53 & 65.74 & & \\
\hline & $\begin{array}{l}\text { Architecture, building and } \\
\text { planning }\end{array}$ & $6.64 \%$ & 61.98 & 59.75 & 63.15 & & \\
\hline & Social studies & $11.46 \%$ & 60.19 & 58.89 & 60.95 & & \\
\hline & Law & $3.79 \%$ & 59.17 & 54.87 & 61.54 & & \\
\hline & $\begin{array}{l}\text { Business and administrative } \\
\text { studies }\end{array}$ & $19.32 \%$ & 61.38 & 59.87 & 62.30 & & \\
\hline & $\begin{array}{l}\text { Mass communication and } \\
\text { documentation }\end{array}$ & $4.24 \%$ & 61.22 & 59.21 & 62.31 & & \\
\hline & $\begin{array}{l}\text { Linguistics, classics and } \\
\text { related }\end{array}$ & $4.45 \%$ & 60.98 & 58.83 & 62.16 & & \\
\hline & $\begin{array}{l}\text { European and non-European } \\
\text { languages, literature and } \\
\text { related }\end{array}$ & $1.89 \%$ & 62.69 & 62.38 & 62.74 & & \\
\hline & $\begin{array}{l}\text { Historical and philosophical } \\
\text { studies }\end{array}$ & $9.37 \%$ & 61.67 & 59.87 & 62.65 & & \\
\hline & Creative arts and design & $3.30 \%$ & 62.99 & 62.58 & 63.19 & & \\
\hline & Education & $4.38 \%$ & 61.74 & 59.97 & 62.64 & & \\
\hline & Total known & \multicolumn{4}{|c|}{ Known for all } & & \\
\hline \multicolumn{3}{|c|}{ Total } & 61.73 & 60.42 & 62.46 & & \\
\hline
\end{tabular}

*Significance level $<0.05$

$* *$ Significance level $<0.01$

$* * *$ Significance level $<0.001$ 
Table 2. Regression - All modules average module mark (2012/13 and 2013/14 cohort start year)

\begin{tabular}{|c|c|c|c|}
\hline \multicolumn{4}{|c|}{ Dependent variable: All modules average module mark } \\
\hline \multirow{2}{*}{$\begin{array}{c}\mathrm{R}^{2} \\
\text { Model }\end{array}$} & \multicolumn{3}{|c|}{0.116} \\
\hline & $\begin{array}{c}\text { B } \\
\text { coefficient }\end{array}$ & $\mathbf{t}$ & Sig. \\
\hline Constant & 62.14 & 65.40 & 0.000 \\
\hline GPA introduction & 0.47 & 2.30 & 0.021 \\
\hline Gender- Male & -0.60 & -2.71 & 0.007 \\
\hline Ethnicity - Asian (ref: White) & -1.53 & -2.87 & 0.004 \\
\hline Ethnicity - Black (ref: White) & -2.61 & -4.44 & $\mathbf{0 . 0 0 0}$ \\
\hline Ethnicity - Other (ref: White) & -1.79 & -4.37 & 0.000 \\
\hline Entry age - Mature (without honours degree) & 2.20 & 4.64 & 0.000 \\
\hline Subject - Subjects allied to medicine (ref: Computer Science) & -4.39 & -4.98 & 0.000 \\
\hline Subject - Biological sciences (ref: Computer Science) & -4.39 & -5.11 & 0.000 \\
\hline Subject - Physical and mathematical sciences (ref: Computer & & & \\
\hline Science) & -4.33 & -3.83 & 0.000 \\
\hline Subject - Engineering and technologies (ref: Computer & & & \\
\hline Science) & -2.46 & -2.48 & 0.013 \\
\hline Subject - Architecture, building and planning (ref: Computer & & & \\
\hline Science) & -5.19 & -5.82 & 0.000 \\
\hline Subject - Social studies (ref: Computer Science) & -6.06 & -7.04 & 0.000 \\
\hline Subject - Law (ref: Computer Science) & -7.56 & -7.87 & 0.000 \\
\hline Subject - Business and administrative studies (ref: Computer & & & \\
\hline Science) & -5.00 & -5.97 & 0.000 \\
\hline Subject - Mass communication and documentation (ref: & & & \\
\hline Computer Science) & -5.62 & -5.96 & 0.000 \\
\hline Subject - Linguistics, classics and related (ref: Computer & & & \\
\hline Science) & -5.89 & -6.29 & 0.000 \\
\hline $\begin{array}{l}\text { Subject - European and non-European languages, literature } \\
\text { and related (ref: Computer Science) }\end{array}$ & -3.66 & -3.37 & 0.001 \\
\hline Subject - Historical and philosophical studies (ref: Computer & & & \\
\hline Science) & -5.03 & -5.77 & 0.000 \\
\hline Subject - Creative arts and design (ref: Computer Science) & -4.47 & -4.55 & 0.000 \\
\hline Subject - Education (ref: Computer Science) & -5.31 & -5.61 & 0.000 \\
\hline Average entry tariff & 0.01 & 11.48 & 0.000 \\
\hline
\end{tabular}


Table 3. Regression - Stage 1 average module mark (2012/13 and 2013/14 cohort start year)

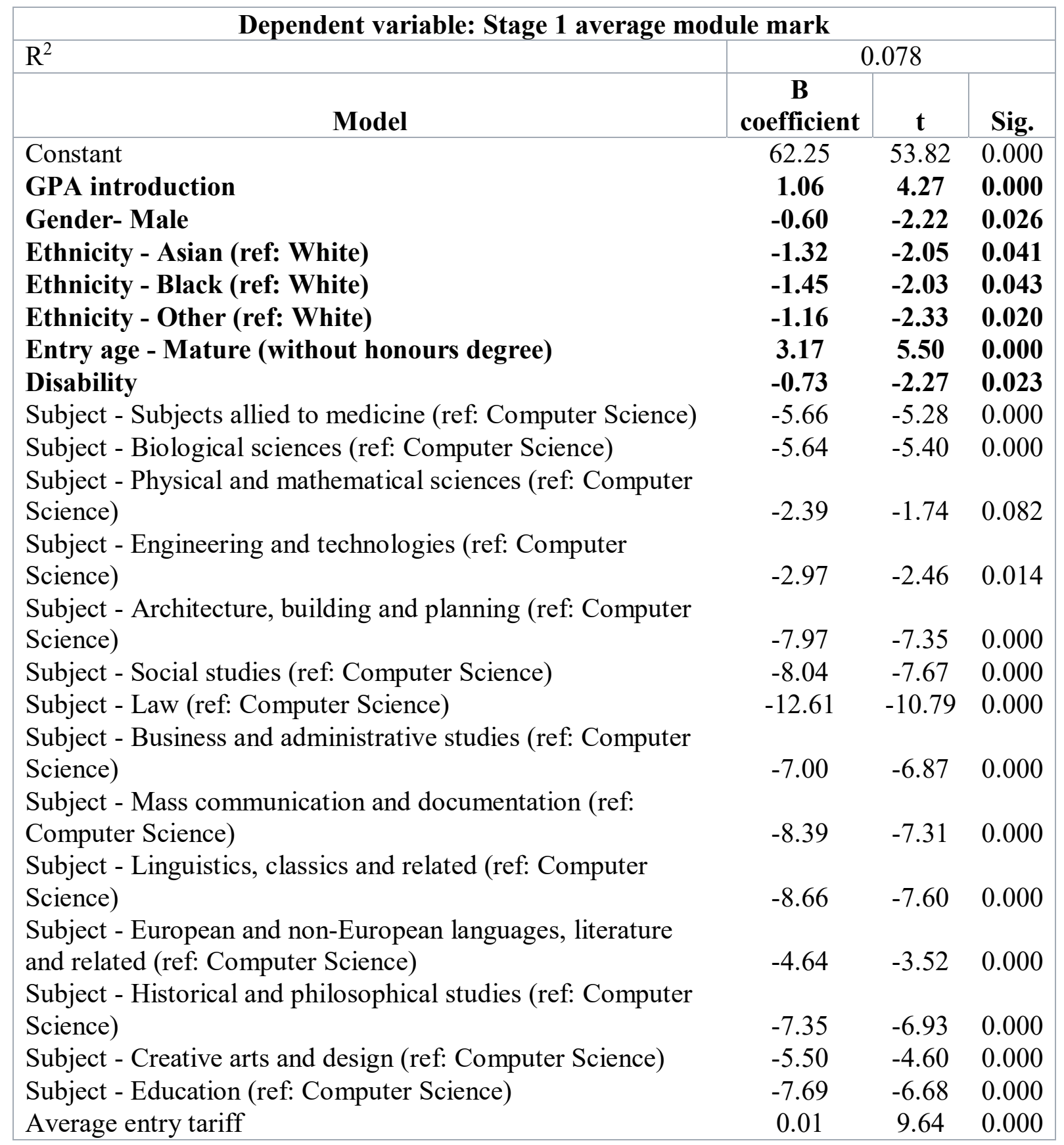


Table 4. Regression - Stage 2 average module mark (2012/13 and 2013/14 cohort start year)

\begin{tabular}{|c|c|c|c|}
\hline \multicolumn{4}{|c|}{ Dependent variable: Stage 2 average module mark } \\
\hline \multirow[b]{2}{*}{ Model } & \multicolumn{3}{|c|}{0.082} \\
\hline & $\begin{array}{c}\text { B } \\
\text { coefficient }\end{array}$ & $\mathbf{t}$ & Sig. \\
\hline Constant & 62.09 & 63.59 & 0.000 \\
\hline GPA introduction & 0.14 & 0.68 & 0.497 \\
\hline Gender- Male & -0.58 & -2.57 & 0.010 \\
\hline Ethnicity - Asian (ref: White) & -1.67 & -3.05 & 0.002 \\
\hline Ethnicity - Black (ref: White) & -3.23 & $-\mathbf{5 . 3 5}$ & 0.000 \\
\hline Ethnicity - Other (ref: White) & -2.16 & -5.13 & $\mathbf{0 . 0 0 0}$ \\
\hline Entry age - Mature (without honours degree) & 1.85 & 3.80 & $\mathbf{0 . 0 0 0}$ \\
\hline Subject - Subjects allied to medicine (ref: Computer Science) & -3.66 & -4.04 & 0.000 \\
\hline Subject - Biological sciences (ref: Computer Science) & -3.58 & -4.06 & 0.000 \\
\hline Subject - Physical and mathematical sciences (ref: Computer & & & \\
\hline Science) & -5.18 & -4.46 & 0.000 \\
\hline Subject - Engineering and technologies (ref: Computer & & & \\
\hline Science) & -2.03 & -2.00 & 0.046 \\
\hline Subject - Architecture, building and planning (ref: Computer & & & \\
\hline Science) & -3.62 & -3.95 & 0.000 \\
\hline Subject - Social studies (ref: Computer Science) & -4.85 & -5.48 & 0.000 \\
\hline Subject - Law (ref: Computer Science) & -4.73 & -4.79 & 0.000 \\
\hline Subject - Business and administrative studies (ref: Computer & & & \\
\hline Science) & -3.71 & -4.32 & 0.000 \\
\hline Subject - Mass communication and documentation (ref: & & & \\
\hline Computer Science) & -4.07 & -4.20 & 0.000 \\
\hline Subject - Linguistics, classics and related (ref: Computer & & & \\
\hline Science) & -4.31 & -4.48 & 0.000 \\
\hline $\begin{array}{l}\text { Subject - European and non-European languages, literature } \\
\text { and related (ref: Computer Science) }\end{array}$ & -3.22 & -2.89 & 0.004 \\
\hline Subject - Historical and philosophical studies (ref: Computer & & & \\
\hline Science) & -3.68 & -4.11 & 0.000 \\
\hline Subject - Creative arts and design (ref: Computer Science) & -3.81 & -3.77 & 0.000 \\
\hline Subject - Education (ref: Computer Science) & -3.98 & -4.09 & 0.000 \\
\hline Average entry tariff & 0.01 & 10.95 & 0.000 \\
\hline
\end{tabular}


Table 5. Regression - Difference between Stage 2 and Stage 1 average module mark (2012/13 and 2013/14 cohort start year)

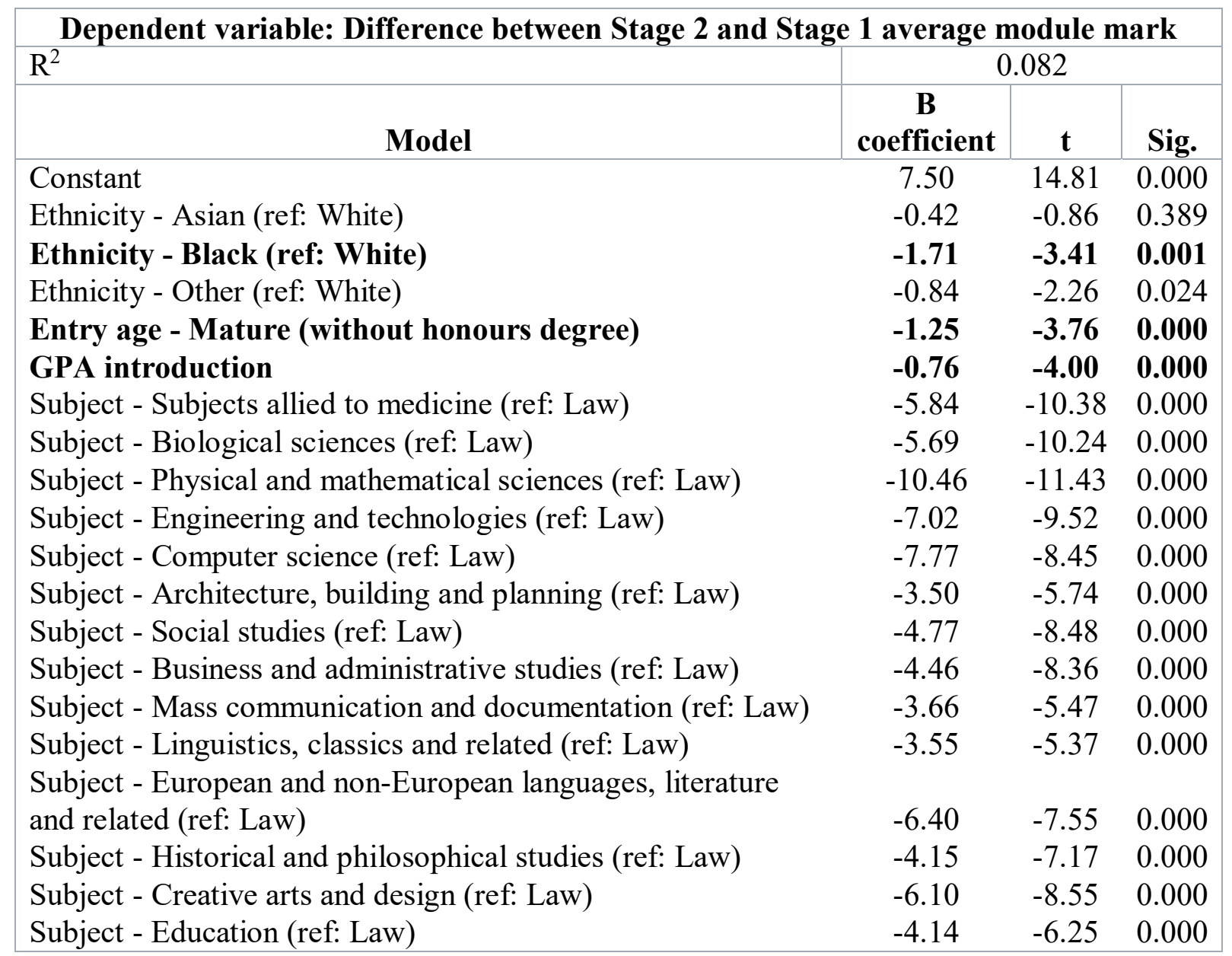


Table 5a. Regression - Difference between Stage 2 and Stage 1 average module mark (2013/14 cohort start year)

Dependent variable: Difference between Stage 2 and Stage 1 average module mark $(2013 / 14)$

\begin{tabular}{|c|c|c|c|}
\hline \multirow[b]{2}{*}{ Model } & \multicolumn{3}{|c|}{0.103} \\
\hline & $\begin{array}{c}\text { B } \\
\text { coefficient }\end{array}$ & $\mathbf{t}$ & Sig. \\
\hline Constant & 8.50 & 13.77 & 0.000 \\
\hline Ethnicity - Asian (ref: White) & -0.35 & -0.52 & 0.601 \\
\hline Ethnicity - Black (ref: White) & -1.32 & -2.05 & 0.041 \\
\hline Ethnicity - Other (ref: White) & -1.30 & -2.68 & 0.008 \\
\hline Entry age - Mature (without honours degree) & -1.11 & -2.37 & 0.018 \\
\hline Subject - Subjects allied to medicine (ref: Law) & -7.22 & -10.08 & 0.000 \\
\hline Subject - Biological sciences (ref: Law) & -7.60 & -10.93 & 0.000 \\
\hline Subject - Physical and mathematical sciences (ref: Law) & -10.62 & -8.54 & 0.000 \\
\hline Subject - Engineering and technologies (ref: Law) & -9.37 & -9.71 & 0.000 \\
\hline Subject - Computer science (ref: Law) & -12.64 & -9.67 & 0.000 \\
\hline Subject - Architecture, building and planning (ref: Law) & -6.15 & -7.82 & 0.000 \\
\hline Subject - Social studies (ref: Law) & -5.88 & -8.36 & 0.000 \\
\hline Subject - Business and administrative studies (ref: Law) & -6.38 & -9.45 & 0.000 \\
\hline Subject - Mass communication and documentation (ref: Law) & -5.60 & -6.56 & 0.000 \\
\hline Subject - Linguistics, classics and related (ref: Law) & -5.87 & -7.10 & 0.000 \\
\hline $\begin{array}{l}\text { Subject - European and non-European languages, literature } \\
\text { and related (ref: Law) }\end{array}$ & -8.56 & -7.63 & 0.000 \\
\hline Subject - Historical and philosophical studies (ref: Law) & -5.99 & -8.19 & 0.000 \\
\hline Subject - Creative arts and design (ref: Law) & -7.69 & -8.72 & 0.000 \\
\hline Subject - Education (ref: Law) & -6.19 & -7.43 & 0.000 \\
\hline
\end{tabular}


Table 5b. Regression - Difference between Stage 2 and Stage 1 average module mark (2012/13 cohort start year)

Dependent variable: Difference between Stage 2 and Stage 1 average module mark $(2012 / 13)$

\begin{tabular}{|c|c|c|c|}
\hline \multirow[b]{2}{*}{ Model } & \multicolumn{3}{|c|}{0.096} \\
\hline & $\begin{array}{c}\text { B } \\
\text { coefficient }\end{array}$ & $\mathbf{t}$ & Sig. \\
\hline Constant & 4.80 & 5.99 & 0.000 \\
\hline Ethnicity - Asian (ref: White) & -0.64 & -0.87 & 0.382 \\
\hline Ethnicity - Black (ref: White) & -2.15 & -2.75 & 0.006 \\
\hline Ethnicity - Other (ref: White) & -0.46 & -0.79 & 0.430 \\
\hline Entry age - Mature (without honours degree) & -1.49 & -3.16 & 0.002 \\
\hline Subject - Subjects allied to medicine (ref: Law) & -3.52 & -3.92 & 0.000 \\
\hline Subject - Biological sciences (ref: Law) & -2.69 & -2.98 & 0.003 \\
\hline Subject - Physical and mathematical sciences (ref: Law) & -9.29 & -6.86 & 0.000 \\
\hline Subject - Engineering and technologies (ref: Law) & -3.66 & -3.22 & 0.001 \\
\hline Subject - Computer science (ref: Law) & -2.67 & -2.02 & 0.043 \\
\hline Subject - Architecture, building and planning (ref: Law) & 0.13 & 0.14 & 0.890 \\
\hline Subject - Social studies (ref: Law) & -3.00 & -3.29 & 0.001 \\
\hline Subject - Business and administrative studies (ref: Law) & -1.56 & -1.82 & 0.069 \\
\hline Subject - Mass communication and documentation (ref: Law) & -0.71 & -0.67 & 0.503 \\
\hline Subject - Linguistics, classics and related (ref: Law) & 0.01 & 0.01 & 0.994 \\
\hline $\begin{array}{l}\text { Subject - European and non-European languages, literature } \\
\text { and related (ref: Law) }\end{array}$ & -3.30 & -2.56 & 0.011 \\
\hline Subject - Historical and philosophical studies (ref: Law) & -1.31 & -1.41 & 0.158 \\
\hline Subject - Creative arts and design (ref: Law) & -3.59 & -3.05 & 0.002 \\
\hline Subject - Education (ref: Law) & -0.98 & -0.91 & 0.362 \\
\hline
\end{tabular}


Table 6. Ethnicity and entry age and attainment: GPA and degree classification

\begin{tabular}{|c|c|c|c|c|c|c|c|}
\hline & Variable & $\begin{array}{c}\text { GP } \\
\text { A }\end{array}$ & $\begin{array}{l}\text { Statistical } \\
\text { significance - } \\
\text { multivariate } \\
\text { regression } \\
\text { (linear) }\end{array}$ & $\begin{array}{c}\% \text { of } \\
1^{\text {st }} \text { and } \\
2.1 \\
\text { degrees }\end{array}$ & $\begin{array}{c}\text { Statistical } \\
\text { significance - } \\
\text { multivariate } \\
\text { regression } \\
\text { (binary logistic) }\end{array}$ & $\begin{array}{c}\text { o of } 1^{\text {st }} \\
\text { class } \\
\text { degrees }\end{array}$ & $\begin{array}{c}\text { Statistical } \\
\text { significance - } \\
\text { multivariate } \\
\text { regression } \\
\text { (binary } \\
\text { logistic) }\end{array}$ \\
\hline \multirow[b]{5}{*}{$\begin{array}{l}\text { Ethn } \\
\text { icity }\end{array}$} & BAME: & 2.78 & \multirow{5}{*}{$\begin{array}{l}\text { Yes }- \\
\text { B coefficient } \\
\text { B }_{\text {BAME }}-0.18 \\
\text { B }_{\text {Asian }}-0.15 \\
\text { B }_{\text {Black }}-0.24 \\
\text { B }_{\text {Other }}-0.18\end{array}$} & $69.4 \%$ & \multirow{5}{*}{$\begin{array}{l}\text { Yes - odds } \\
\text { ratio: } \\
\text { BAME vs White } \\
0.46 \\
\text { Asian vs White } \\
0.61 \\
\text { Black vs White } \\
0.36 \\
\text { Other vs White } \\
0.45\end{array}$} & $12.6 \%$ & \multirow{5}{*}{$\begin{array}{l}\text { Yes apart from } \\
\text { Asian vs White } \\
\text { differences - } \\
\text { odds ratio: } \\
\text { BAME vs } \\
\text { White } 0.54 \\
\text { Black vs White } \\
0.30 \\
\text { Other vs White } \\
0.59\end{array}$} \\
\hline & - Asian & 2.82 & & $74.8 \%$ & & $14.1 \%$ & \\
\hline & - Black & 2.70 & & $64.1 \%$ & & $6.9 \%$ & \\
\hline & - Other & 2.81 & & $69.1 \%$ & & $14.8 \%$ & \\
\hline & White & 3.00 & & $83.7 \%$ & & $22.6 \%$ & \\
\hline \multirow[t]{2}{*}{$\begin{array}{l}\text { Entr } \\
\text { y } \\
\text { age }\end{array}$} & $\begin{array}{l}\text { Mature } \\
\text { (without } \\
\text { honours } \\
\text { degree) }\end{array}$ & 2.95 & \multirow[t]{2}{*}{$\begin{array}{l}\text { Yes - B } \\
\text { coefficient } \\
0.18\end{array}$} & $73.3 \%$ & \multirow[t]{2}{*}{ No } & $28.4 \%$ & \multirow[t]{2}{*}{$\begin{array}{l}\text { Yes - odds } \\
\text { ratio } \\
\text { Mature vs } \\
\text { Young } 2.6\end{array}$} \\
\hline & Young & 2.97 & & $82.5 \%$ & & $20.3 \%$ & \\
\hline
\end{tabular}

